\title{
UJI EFEKTIVITAS KEMATIAN LARVA NYAMUK AEDES AEGYPTI DENGAN MENGGUNAKAN BERBAGAI JENIS LARVASIDA
}

\author{
Ronald William Anthonio $\mathbf{T}^{1)}$, Warsiyah ${ }^{2)}$, Warniningsih ${ }^{3)}$ \\ 1) 2) ${ }^{3)}$ Program Studi Teknik Lingkungan, Institut Teknologi Yogyakarta \\ email: ronnytuasela89@gmail.com
}

\begin{abstract}
ABSTRAK
Kasus DBD sejak ditemukannya pada tahun 1968 terus mengalami peningkatan dan menyebar ke seluruh Indonesia. Vektor penyakit DBD yaitu nyamuk Aedes aegypti dan Aedes albopictus masih banyak dijumpai di wilayah Indonesia. Pengendalian larva Aedes aegypti, selain dilakukan secara kimiawi, juga dapat dilakukan secara nabati. Penelitian ini bertujuan untuk mengetahui tingkat efektivitas kematian larva nyamuk Aedes aegypty dengan menggunakan jenis larvasida Temephos, ekstrak daun tembakau, dan dan ekstrak daun jeruk purut dan untuk mengetahui perbandingan efektivitas kematian larva nyamuk Aedes aegypti dengan menggunakan berbagai jenis larvasida Temephos, ekstrak daun tembakau, dan ekstrak daun jeruk purut.

Jenis penelitian yang dilakukan adalah eksperimen, yaitu suatu penelitian dengan melakukan kegiatan percobaan, yang bertujuan untuk mengetahui gejala atau pengaruh yang timbul sebagai akibat dari adanya perlakukan tertentu, dengan rancangan peneliitian Posttest only control group Design.

Hasil penelitian menunjukkan bahwa Temephos, ekstrak daun tembakau, dan ekstrak daun jeruk purut, dapat menjadi larvasida untuk membunuh larva Aedes aegypti. Temephos membutuhkan waktu 7 jam untuk membunuh semua larva dengan perbandingan dosis $70 \mathrm{ml} / 25$ ekor jentik Aedes aegypti. Ekstrak daun tembakau membutuhkan waktu 12 jam untuk membunuh semua larva dengan perbandingan dosis $70 \mathrm{ml} / 25$ ekor jentik Aedes aegypti. Sedangkan, ekstrak daun jeruk purut membutuhkan waktu 12 jam untuk membunuh semua larva dengan perbandingan dosis $70 \mathrm{ml} / 25$ ekor jentik Aedes aegypti. Temephos adalah yang paling bagus sebagai larvasida.
\end{abstract}

Kata Kunci: Larvasida, Aedes Aegypti, Temephos, Ekstrak Daun Tembakau, Ekstrak Daun Jeruk Purut

\section{EFFECTIVENESS TEST OF THE DEATH OF AEDES AEGYPTI LARVA USING VARIOUS TYPE OF LARVACIDES}

\begin{abstract}
The case of DHF since its discovery in 1968 has continued to increase and spread throughout Indonesia. The vector of dengue disease, namely Aedes aegypti and Aides albopictus mosquitoes is still commonly found in Indonesia. Control of Aedes aegypti larvae, in addition to being carried out chemically, can also be done vegetable-based. This study aims to determine the effectiveness of the death of Aedes aegypty mosquito larvae using Temephos larvicides, tobacco leaf extract, and kaffir lime leaf extract and then to compare the effectiveness of the death of Aedes aegypti mosquito larvae using Temephos, tobacco leaf extract, and extract of kaffir lime leaves.

This type of research is an experiment, which is a study by conducting experimental activities, which aims to determine the symptoms or effects that arise as a result of certain treatments, with the design of the Posttest only control group Design.

The results showed that Temephos, tobacco leaf extract, and kaffir lime leaf extract, could be larvacidal to kill Aedes aegypti larvae. Temephos takes 7 hours to kill all larvae with a doses ratio of $70 \mathrm{ml} / 25$ Aedes aegypti larvaes. Tobacco leaf extract takes 12 hours to kill all larvae with a doses ratio of $70 \mathrm{ml} / 25$ Aedes aegypti larvaes. Meanwhile, kaffir lime leaf extract takes 12 hours to kill all larvae with a doses ratio of 70ml / 25 Aedes aegypti larvaes. Temephoss is the the best and most effective as a larvacide.
\end{abstract}

Keywords: Larvacides, Aedes Aegypti, Temephos, Tobacco Leaf Extract, Kaffir lime Leaves Extract

\section{PENDAHULUAN}

Latar Belakang

Menurut Soegijanto (2006), sampai saat ini penyakit demam berdarah dengue (DBD) masih menjadi masalah kesehatan masyarakat di Indonesia. Hal ini didukung oleh data-data seperti: (1) sejak ditemukannya kasus DBD pada tahun 1968 di Surabaya dan Jakarta, angka kejadian penyakit DBD terus meningkat dan menyebar ke seluruh daerah kabupaten di wilayah Republik Indonesia, (2) pada pengamatan selama kurun waktu 20-25 tahun sejak awal ditemukan kasus DBD, angka kejadian luar 
biasa (KLB) penyakit DBD diestimasikan terjadi setiap 5 tahun dengan angka kematian tertinggi pada tahun 1968 saat awal ditemukan kasus DBD dan angka kejadian penyakit DBD tertinggi pada tahun 1988, (3) angka kematian kasus DBD masih tinggi, terutama penderita DBD yang datang terlambat dengan derajat IV, (4) vektor penyakit DBD yaitu nyamuk Aedes aegypti dan Aedes albopictus masih banyak dijumpai di wilayah Indonesia, dan (5) kemajuan teknologi.

Menurut Llyod yang dikutip oleh Supartha (2008), serangan penyakit DBD berimplikasi luas terhadap kerugian moral dan material berupa biaya rumah sakit dan pengobatan pasien, kehilangan produktivitas kerja bagi penderita, kehilangan wisatawan akibat pemberitaan buruk terhadap daerah kejadian dan yang paling fatal adalah kehilangan nyawa (Supartha, 2008).

Di Yogyakarta terjadi wabah demam berdarah pertama di Bantul pada tahun 1976, dari semua penderita DBD yang meninggal telah berhasil di isolasi virus Dengue tipe 3. Virus Dengue tipe 3 merupakan serotipe yang terbanyak berhasil diisolasi $(48,6 \%)$ disusul berturut-turut oleh virus dengue tipe $2(28,6 \%)$ kemudian virus dengue tipe 1 (20\%) dan virus tipe 4 (2,9\%) (Hadinegoro, 2002:6).

Penyakit DBD sangat dipengaruhi lingkungan dan perilaku manusia karena penyebab penyakit ini adalah virus yang dapat menyebar melalui vektor yaitu nyamuk Aedes aegypti. Nyamuk ini mempunyai perilaku hidup di tempat air jernih yang akan berkembangbiak dalam waktu $7-10$ hari. Cara efektif untuk pencegahan penyakit DBD adalah dengan membasmi larva Aedes aegypti melalui gerakan PSN (Dinas Kesehatan Jawa Tengah, 2003).

Secara universal belum ditemukan adanya vaksin sebagai alat pencegahan penyakit DBD (Kemenkes, 2013), sehingga perlu dilakukan pengendalian populasi vektor DBD, yaitu nyamuk Aedes aegepti. Pengendalian populasi vektor nyamuk pada tahap larva lebih mudah dilakukan dibandingkan tahap lain dari fase hidup nyamuk.

Pemberantasan larva Aegypti telah dilakukan denagan berbagai cara dan pengendalian yang paling banyak dilakukan adalah pengendalian secara kimiawi. Hasil penelitian menunjukkan bahwa Aedes aegypti resisten terhadap penggunaan temephos (Susanto, 2010).

Selama pengendalian secara kimiawi, dapat juga menggunakan pengendalian secara nabati atau alami. Variasi larvasida seperti penggunaan larvasida nabati dapat juga berfungsi sebagai pencegahan timbulnnya resistensi pada organisme sasaran (Purnama, 2012)

Senyawa yang berpontensi sebagai larvasida antara lain golongan sianisa, saponin, tanin, flavonoid, minyak astiri, nikotin, dan streoid. Tanaman tembakau mengandung alkaloid, flavonoid, minyak astiri, dan nikotin, sehingga tanaman tembakau dapat berpontesi sebagai larvasida (Zaidi et al 2004). Selain itu jenis larvasida alami/nabati yang dapat digunakan untuk mengendalikan larva Aedes Aegypti adalah daun jeruk purut. Jeruk purut merupakan salah satu spesies dari famili Rutaceae. Komponen minyak astiri dari minyak tersebut memiliki potensi sebagai insektisida alternatif. Daun jeruk purut memiliki kandungan minyak astiri, tannin, dan triterpenoid yang merupakan senyawa bioaktif larvasida (Dalimartha, 2000).

Berdasarkan uraian tersebut di atas, peneliti tertarik melakukan penelitian untuk mengetahui perbandingan efektivitas kematian larva nyamuk Aedes aegypti dengan menggunakan berbagai jenis larvasida.

\section{Rumusan Masalah}

Rumusan masalah dalam penelitian ini adalah sebagai berikut:

(1) Bagaimana tingkat efektivtas kematian larva nyamuk Aedes aegypty dengan menggunakan jenis larvasida Temephos, ekstrak daun tembakau, dan dan ekstrak daun jeruk purut?

(2) Bagaimana perbandingan efektivitas kematian larva nyamuk Aedes aegypti dengan menggunakan berbagai jenis larvasida Temephos, ekstrak daun tembakau, dan ekstrak daun jeruk purut?

\section{Batasan Masalah}

Batasan masalah pada penelitian ini adalah:

(1) Jenis bahan yang digunakan pada penelitian ini adalah Temephos, daun tembakau yang telah diekstrak, dan daun jeruk purut.

(2) Dosis ekstrak Temephos, ekstrak daun tembakau, dan ekstrak daun jeruk purut adalah $0 \mathrm{ml}, 10 \mathrm{ml}$, $20 \mathrm{ml}, 30 \mathrm{ml}, 40 \mathrm{ml}, 50 \mathrm{ml}, 60 \mathrm{ml}$, dan $70 \mathrm{ml}$.

(3) Parameter yang diperiksa adalah efektivitas Temephos, daun tembakau, dan daun jeruk purut sebagai larvasida Aedes aegeypti. 


\section{Tujuan Penelitian}

Tujuan dari penelitian ini adalah:

(1) Untuk mengetahui tingkat efektivitas kematian larva nyamuk Aedes aegypty dengan menggunakan jenis larvasida Temephos, ekstrak daun tembakau, dan dan ekstrak daun jeruk purut.

(2) Untuk mengetahui perbandingan efektivitas kematian larva nyamuk Aedes aegypti dengan menggunakan berbagai jenis larvasida Temephos, ekstrak daun tembakau, dan ekstrak daun jeruk purut.

\section{METODE PENELITIAN}

\section{Jenis Penelitian}

Jenis penelitian yang dilakukan adalah eksperimen, yaitu suatu penelitian dengan melakukan kegiatan percobaan, yang bertujuan untuk mengetahui gejala atau pengaruh yang timbul sebagai akibat dari adanya perlakukan tertentu, dengan rancangan peneliitian Posttest only control group Design (Notoadmodjo, 2012).

\section{Bahan Penelitian}

Bahan yang digunakan dalam penelitian ini adalah ekstrak daun tembakau, ekstrak daun jeruk purut, dan Temephos dengan takaran $0 \mathrm{ml}, 10 \mathrm{ml}, 20 \mathrm{ml}, 30 \mathrm{ml}, 40 \mathrm{ml}, 50 \mathrm{ml}, 60 \mathrm{ml}$, dan $70 \mathrm{ml}$. Larva uji yang digunakan adalah larva Aedes Aegypti hasil kolonisasi dari jentik instar III atau yang berumur 7 hari yang diperoleh dari pembelian jentik di pasar satwa. Jumlah larva yang digunakan adalah sekitar 632 larva Aedes Aegypti dengan masing-masing 7 (tujuh) kali perlakuan dan tiap kolonisasi diisi 25 ekor nyamuk Aedes Aegypti. Pengamatan kematian larva Aedes Aegypti dilakukan setiap satu jam selama 24 jam (Komisi Pestisida, 1995).

\section{Variabel Penelitian dan Definisi Operasional}

Variabel independen adalah variabel yang mempengaruhi variabel dependen, yaitu ekstrak daun tembakau, ekstrak daun jeruk purut, dan Temephos dengan takaran $0 \mathrm{ml}, 10 \mathrm{ml}, 20 \mathrm{ml}, 30 \mathrm{ml}, 40 \mathrm{ml}$, $50 \mathrm{ml}, 60 \mathrm{ml}$, dan $70 \mathrm{ml}$.

Variabel dependen adalah variabel yang dipengaruhi oleh variabel independen, yaitu larva Aedes Aegypti yang mengalami kematian.

\section{Teknik Pengumpulan Data}

Data primer adalah data yang diperoleh dari hasil kegiatan penelitian, yaitu ekstrak daun tembakau, ekstrak daun jeruk purut, dan Temephos sebanyak $0 \mathrm{ml}, 10 \mathrm{ml}, 20 \mathrm{ml}, 30 \mathrm{ml}, 40 \mathrm{ml}, 50 \mathrm{ml}$, $60 \mathrm{ml}$, dan $70 \mathrm{ml}$ dan jumlah nyamuk mati pada masing-masing uji.

Data sekunder adalah data kasus DBD yang diperoleh dari instansi lain. Data sekunder ini diperoleh dari berbagai sumber referensi yang berhubungan dengan penelitian tersebut.

\section{Analisa Data}

Analisis data yang digunakan dalam penelitian ini adalah menggunakan rumus yang digunakan untuk menghitung persentase kematian larva, yaitu:

$\%$ Kematian $=\frac{\text { Jumlah larvamati }}{\text { Jumlah larva uji }} \times 100 \%$.

(Rumus perhitungan persentase kematian larva).

\section{HASIL DAN PEMBAHASAN}

\section{Perbandingan Efektivitas Larvasida Per Dosis}

\section{(1) Perbandingan Dosis 10ml}

Berdasarkan hasil percobaan dapat diketahui bahwa pada dosis $10 \mathrm{ml}$ ekstrak daun tembakau membutuhkan waktu 14 (empat belas) jam untuk membunuh 25 ekor larva Aedes aegypti, dengan perincian sebagai berikut: 1 ekor (4\%) pada jam ketujuh, 2 ekor (8\%) pada jam kedelapan, 3 ekor (12\%) pada masing-masing jam kesembilan dan jam kesepuluh, dan masing-masing 4 ekor (16\%) pada jam kesebelas, keduabelas, ketigabelas, dan keempatbelas. 
Ekstrak daun jeruk purut pada dosis $10 \mathrm{ml}$ membutuhkan waktu 16 (enambelas) jam untuk membunuh 25 ekor larva Aedes aegypti, dengan perincian sebagai berikut: masing-masing 1 ekor (4\%) pada jam ketujuh, kedelapan, dan kesembilan; 2 akor (8\%) pada jam kesepuluh; masingmasing 3 ekor (12\%) pada jam kesebelas, keduabelas, ketigabelas, dan keempatbelas; dan masing-masing 4 ekor (16\%) pada jam kelimabelas dan keenambelas.

Temephos pada dosis $10 \mathrm{ml}$ membutuhkan waktu 7 (tujuh) jam untuk membunuh 25 ekor larva Aedes aegypti, dengan perincian sebagai berikut: 1 ekor larva (4\%) pada jam pertama; 2 ekor (8\%) pada jam kedua; masing-masing 3 ekor (12\%) pada jam ketiga dan keempat; 4 ekor (16\%) pada jam kelima; dan masing-masing 6 ekor (24\%) pada jam keenam dan jam ketujuh.

Berdasarkan uraian di atas, dapat disimpulkan bahwa pada dosis $10 \mathrm{ml}$, Temephos menjadi larvasida yang paling efektif karena hanya membutuhkan waktu 7 (tujuh) jam untuk membunuh keseluruhan larva, kemudian diikuti oleh ekstrak daun tembakau dengan waktu 14 (empat belas) jam, dan kemudian diikuti oleh ekstrak daun jeruk purut dengan waktu 16 jam.

\section{(2) Perbandingan pada Dosis $20 \mathrm{ml}$}

Berdasarkan hasil percobaan dapat diketahui bahwa pada dosis $20 \mathrm{ml}$ ekstrak daun tembakau membutuhkan waktu 14 (empat belas) jam untuk membunuh 25 ekor larva Aedes aegypti, dengan perincian sebagai berikut: masing-masing 1 ekor (4\%) pada jam keenam dan ketujuh; 2 ekor (8\%) pada jam kedelapan; masing-masing 3 ekor (12\%) pada masing-masing jam kesembilan dan jam kesepuluh, dan masing-masing 4 ekor (16\%) pada jam kesebelas, keduabelas, ketigabelas, dan keempatbelas.

Ekstrak daun jeruk purut pada dosis 20ml membutuhkan waktu 15 (limabelas) jam untuk membunuh 25 ekor larva Aedes aegypti, dengan perincian sebagai berikut: masing-masing 1 ekor (4\%) pada jam ketujuh dan kedelapan; 2 akor (8\%) pada jam kesembilan dan kesepuluh; masingmasing 3 ekor (12\%) pada jam kesebelas dan keduabelas; dan masing-masing 4 ekor (16 ekor) pada jam ketigabelas dan keempatbelas; dan 5 ekor (20\%) pada jam kelimabelas.

Temephos pada dosis $20 \mathrm{ml}$ membutuhkan waktu 7 (tujuh) jam untuk membunuh 25 ekor larva Aedes aegypti, dengan perincian sebagai berikut: masing-masing 2 ekor larva (8\%) pada jam pertama dan kedua; masing-masing 3 ekor (12\%) pada jam ketiga, keempat, dan kelima; 5 ekor (20\%) pada jam keenam; 7 ekor (28\%) pada ketujuh.

Berdasarkan uraian di atas, dapat disimpulkan bahwa pada dosis 20ml, Temephos menjadi larvasida yang paling efektif karena hanya membutuhkan waktu 7 (tujuh) jam untuk membunuh keseluruhan larva, kemudian diikuti oleh ekstrak daun tembakau dengan waktu 14 (empat belas) jam, dan kemudian diikuti oleh ekstrak daun jeruk purut selama 15 (limabelas) jam.

\section{(3) Perbandingan pada Dosis 30ml}

Berdasarkan hasil percobaan dapat diketahui bahwa pada dosis 30ml, ekstrak daun tembakau membutuhkan waktu 14 (empatbelas) jam untuk membunuh 25 ekor larva Aedes aegypti, dengan perincian sebagai berikut: masing-masing 1 ekor (4\%) pada jam keenam dan ketujuh; 2 ekor (8\%) pada jam kedelapan; masing-masing 3 ekor (12\%) pada masing-masing jam kesembilan dan jam kesepuluh, 4 ekor (16\%) pada jam kesebelas, 3 ekor $(12 \%)$ pada jam keduabelas, dan masingmasing 4 ekor (16\%) pada jam ketigabelas, dan keempatbelas.

Ekstrak daun jeruk purut pada dosis 30ml membutuhkan waktu 15 (limabelas) jam untuk membunuh 25 ekor larva Aedes aegypti, dengan perincian sebagai berikut: masing-masing 1 ekor (4\%) pada jam ketujuh dan kedelapan; masing-masing 2 akor (8\%) pada jam kesembilan dan kesepuluh; masing-masing 3 ekor (12\%) pada jam kesebelas dan keduabelas; dan masing-masing 4 ekor (16 ekor) pada jam ketigabelas dan keempatbelas; dan 5 ekor (20\%) pada jam kelimabelas.

Temephos pada dosis 30ml membutuhkan waktu 7 (tujuh) jam untuk membunuh 25 ekor larva Aedes aegypti, dengan perincian sebagai berikut: 2 ekor larva (8\%) pada jam pertama; masing-masing 3 ekor (12\%) pada jam kedua, ketiga, dan keempat, 4 ekor (16\%) pada jam kelima; masing 5 ekor (20\%) pada jam keenam dan ketujuh.

Berdasarkan uraian di atas, dapat disimpulkan bahwa pada dosis $30 \mathrm{ml}$, Temephos menjadi larvasida yang paling efektif karena hanya membutuhkan waktu 7 (tujuh) jam untuk membunuh keseluruhan larva, kemudian diikuti oleh ekstrak daun tembakau dengan waktu 14 (empat belas) jam, dan kemudian diikuti oleh ekstrak daun jeruk purut selama 15 (limabelas) jam. 


\section{(4) Perbandingan pada Dosis 40ml}

Berdasarkan hasil percobaan dapat diketahui bahwa pada dosis $40 \mathrm{ml}$, ekstrak daun tembakau membutuhkan waktu 13 (tigabelas) jam untuk membunuh 25 ekor larva Aedes aegypti, dengan perincian sebagai berikut: masing-masing 1 ekor (4\%) pada jam keenam dan ketujuh; 2 ekor (8\%) pada jam kedelapan; 3 ekor (12\%) jam kesembilan; masing-masing 4 ekor (16\%) pada jam kesepuluh dan kesebelas, keduabelas; dan 6 ekor (24\%) pada jam ketigabelas.

Ekstrak daun jeruk purut pada dosis $40 \mathrm{ml}$ membutuhkan waktu 14 (empatbelas) jam untuk membunuh 25 ekor larva Aedes aegypti, dengan perincian sebagai berikut: masing-masing 1 ekor (4\%) pada jam kelima, keenam, ketujuh dan kedelapan; masing-masing 2 akor (8\%) pada jam kesembilan dan kesepuluh; 3 ekor (12\%) pada jam kesebelas; masing-masing 4 ekor (16\%) pada jam keduabelas dan ketigabelas; dan 6 ekor (24 ekor) pada keempatbelas.

Temephos pada dosis 40ml membutuhkan waktu 7 (tujuh) jam untuk membunuh 25 ekor larva Aedes aegypti, dengan perincian sebagai berikut: masing-masing 3 ekor larva (12\%) pada jam pertama, kedua, ketiga, dan keempat; masing-masing 4 ekor (16\%) pada jam kelima dan keenam dan 7 ekor (28\%) pada jam ketujuh.

Berdasarkan uraian di atas, dapat disimpulkan bahwa pada dosis $40 \mathrm{ml}$, Temephos menjadi larvasida yang paling efektif karena hanya membutuhkan waktu 7 (tujuh) jam untuk membunuh keseluruhan larva, kemudian diikuti oleh ekstrak daun tembakau dengan waktu 13 (tigabelas) jam, dan kemudian diikuti oleh ekstrak daun jeruk purut selama 14 (empatbelas) jam.

\section{(5) Perbandingan pada Dosis 50ml}

Berdasarkan hasil percobaan dapat diketahui bahwa pada dosis 50ml, ekstrak daun tembakau membutuhkan waktu 13 (tigabelas) jam untuk membunuh 25 ekor larva Aedes aegypti, dengan perincian sebagai berikut: 1 ekor (4\%) pada jam keenam; masing-masing 2 ekor (8\%) pada jam ketujuh dan kedelapan; masing-masing 3 ekor (12\%) jam kesembilan dan kesepuluh; 4 ekor (16\%) pada jam kesebelas; 6 ekor (24\%) pada jam keduabelas; dan 5 ekor (20\%) pada jam ketigabelas.

Ekstrak daun jeruk purut pada dosis 50ml membutuhkan waktu 14 (empatbelas) jam untuk membunuh 25 ekor larva Aedes aegypti, dengan perincian sebagai berikut: masing-masing 1 ekor (4\%) pada jam kelima, keenam, ketujuh dan kedelapan; 2 akor $(8 \%)$ pada jam kesembilan; masing-masing 3 ekor (12\%) pada jam kesepuluh dan kesebelas; masing-masing 4 ekor (16\%) pada jam keduabelas dan ketigabelas; dan 5 ekor (20 ekor) pada keempatbelas.

Temephos pada dosis 50ml membutuhkan waktu 7 (tujuh) jam untuk membunuh 25 ekor larva Aedes aegypti, dengan perincian sebagai berikut: 3 ekor larva (12\%) pada jam pertama; masing-masing 4 ekor (16\%) pada jam kedua dan ketiga; masing-masing 3 ekor (12\%) pada jam keempat dan kelima; dan 4 ekor (16\%) pada jam keenam dan ketujuh.

Berdasarkan uraian di atas, dapat disimpulkan bahwa pada dosis 50ml, Temephos menjadi larvasida yang paling efektif karena hanya membutuhkan waktu 7 (tujuh) jam untuk membunuh keseluruhan larva, kemudian diikuti oleh ekstrak daun tembakau dengan waktu 13 (tigabelas) jam, dan kemudian diikuti oleh ekstrak daun jeruk purut selama 14 (empatbelas) jam.

\section{(6) Perbandingan pada Dosis 60ml}

Berdasarkan hasil percobaan dapat diketahui bahwa pada dosis $60 \mathrm{ml}$, ekstrak daun tembakau membutuhkan waktu 13 (tigabelas) jam untuk membunuh 25 ekor larva Aedes aegypti, dengan perincian sebagai berikut: masing-masing 1 ekor (4\%) pada jam keenam dan ketujuh; masingmasing 3 ekor (12\%) pada jam kedelapan, kesembilan, dan kesepuluh, dan kesebelas; 4 ekor (16\%) jam keduabelas; dan 7 ekor (28\%) pada jam ketigabelas.

Ekstrak daun jeruk purut pada dosis 60ml membutuhkan waktu 13 (tigabelas) jam untuk membunuh 25 ekor larva Aedes aegypti, dengan perincian sebagai berikut: masing-masing 1 ekor (4\%) pada jam kelima, keenam, ketujuh dan kedelapan; 2 akor (8\%) pada jam kesembilan; 3 ekor (12\%) pada jam kesepuluh; 4 ekor (16\%) pada jam kesebelas; dan masing-masing 6 ekor (24\%) pada jam keduabelas dan ketigabelas.

Temephos pada dosis $60 \mathrm{ml}$ membutuhkan waktu 6 (enam) jam untuk membunuh 25 ekor larva Aedes aegypti, dengan perincian sebagai berikut: 4 ekor larva (16\%) pada jam pertama; 
masing-masing 3 ekor (12\%) pada jam kedua dan ketiga; 4 ekor (16\%) pada jam keempat; 5 ekor (20\%) pada kelima; dan 6 ekor $(24 \%)$ pada jam ketujuh.

Berdasarkan uraian di atas, dapat disimpulkan bahwa pada dosis $60 \mathrm{ml}$, Temephos menjadi larvasida yang paling efektif karena hanya membutuhkan waktu 6 (enam) jam untuk membunuh keseluruhan larva, kemudian diikuti oleh ekstrak daun tembakau dan ekstrak daun jeruk purut dengan masing waktu 13 (tigabelas) jam.

\section{(7) Perbandingan pada Dosis 70ml}

Berdasarkan hasil percobaan dapat diketahui bahwa pada dosis 70ml, ekstrak daun tembakau membutuhkan waktu 12 (duabelas) jam untuk membunuh 25 ekor larva Aedes aegypti, dengan perincian sebagai berikut: masing-masing 2 ekor (8\%) pada jam keenam dan ketujuh; masingmasing 3 ekor (12\%) pada jam kedelapan, kesembilan, dan kesepuluh; 4 ekor (16\%) jam kesebelas; dan 8 ekor (32\%) pada jam keduabelas.

Ekstrak daun jeruk purut pada dosis $70 \mathrm{ml}$ membutuhkan waktu 12 (duabelas) jam untuk membunuh 25 ekor larva Aedes aegypti, dengan perincian sebagai berikut: masing-masing 1 ekor (4\%) pada jam kelima dan keenam; 2 akor (8\%) pada jam ketujuh; masing-masing 3 ekor (12\%) pada jam kedepalan dan kesembilan; 4 ekor (16\%) pada jam kesepuluh; 5 ekor (24\%) pada jam kesebelas; dan 6 ekor pada jam keduabelas.

Temephos pada dosis $70 \mathrm{ml}$ membutuhkan waktu 5 (lima) jam untuk membunuh 25 ekor larva Aedes aegypti, dengan perincian sebagai berikut: masing-masing 4 ekor larva (16\%) pada jam pertama, kedua, ketiga; 6 ekor (24\%) pada jam keempat; dan 5 ekor (20\%) pada ketujuh.

Berdasarkan uraian di atas, dapat disimpulkan bahwa pada dosis $70 \mathrm{ml}$, Temephos menjadi larvasida yang paling efektif karena hanya membutuhkan waktu lima (lima) jam untuk membunuh keseluruhan larva, kemudian diikuti oleh ekstrak daun tembakau dan ekstrak daun jeruk purut dengan masing waktu 12 (tigabelas) jam.

\section{Perbandingan Efektivitas Larvasida Membunuh 100 \% Larva Berdasarkan Dosis}

Perbandingan efektivitas membunuh 100 \% Larva Aedes aegypti Dari Temephos, Ekstrak Daun Tembakau, dan Ekstrak Daun Jeruk Purut berdasarkan dosis, dapat dilihat pada tabel berikut ini:

Tabel 1. Perbandingan Efektivitas Membunuh 100 \% Larva Aedes Aegypti dari Temephos, Ekstrak Daun Tembakau, dan Ekstrak Daun Jeruk Purut

\begin{tabular}{|c|c|c|c|}
\hline Dosis & Larvasida & $\begin{array}{c}\text { Waktu yang } \\
\text { dibutuhkan } \\
\text { membunuh } 100 \% \\
\text { Larva Aedes } \\
\text { aegypti } \\
\end{array}$ & $\begin{array}{c}\text { Skala } \\
\text { Keefektivitasan }\end{array}$ \\
\hline \multirow{3}{*}{$10 \mathrm{ml}$} & Ekstrak Daun Tembakau & $14 \mathrm{Jam}$ & 2 \\
\hline & Ekstrak Daun Jeruk Purut & $16 \mathrm{Jam}$ & 3 \\
\hline & Temephos & 7 Jam & 1 \\
\hline \multirow{3}{*}{$20 \mathrm{ml}$} & Ekstrak Daun Tembakau & $14 \mathrm{Jam}$ & 2 \\
\hline & Ekstrak Daun Jeruk Purut & $15 \mathrm{Jam}$ & 3 \\
\hline & Temephos & 7 Jam & 1 \\
\hline \multirow{3}{*}{$30 \mathrm{ml}$} & Ekstrak Daun Tembakau & 14 Jam & 2 \\
\hline & Ekstrak Daun Jeruk Purut & $15 \mathrm{Jam}$ & 3 \\
\hline & Temephos & $7 \mathrm{Jam}$ & 1 \\
\hline \multirow{3}{*}{$40 \mathrm{ml}$} & Ekstrak Daun Tembakau & $13 \mathrm{Jam}$ & 2 \\
\hline & Ekstrak Daun Jeruk Purut & 14 Jam & 3 \\
\hline & Temephos & $7 \mathrm{Jam}$ & 1 \\
\hline \multirow{3}{*}{$50 \mathrm{ml}$} & Ekstrak Daun Tembakau & $13 \mathrm{Jam}$ & 2 \\
\hline & Ekstrak Daun Jeruk Purut & 14 Jam & 3 \\
\hline & Temephos & $7 \mathrm{Jam}$ & 1 \\
\hline \multirow{3}{*}{$60 \mathrm{ml}$} & Ekstrak Daun Tembakau & $13 \mathrm{Jam}$ & 2 \\
\hline & Ekstrak Daun Jeruk Purut & $13 \mathrm{Jam}$ & 2 \\
\hline & Teтерhos & 7 Jam & 1 \\
\hline
\end{tabular}




\begin{tabular}{llll}
\multirow{2}{*}{$70 \mathrm{ml}$} & Ekstrak Daun Tembakau & 12 Jam & 2 \\
\cline { 2 - 3 } & Ekstrak Daun Jeruk Purut & 12 Jam & 2 \\
\cline { 2 - 3 } & Temephos & 7 Jam & 1
\end{tabular}

Sumber: Data Primer, 2018

Berdasarkan tabel di atas, maka dapat disimpulkan bahwa Temephos merupakan larvasida yang paling efektif untuk membunuh larva Aedes aegypti. Dosis yang paling efektif berdasarkan daya bunuh larva adalah 70ml. Sedangkan larvasida ekstrak daun tembakau dan ekstrak daun jeruk purut juga efektif untuk membunuh larva Aedes aegypti. Dosis yang tepat dan yang paling efektif bagi ekstrak daun tembakau dan ekstrak daun jeruk purut berdasarkan daya bunuh dan kecepatan waktu adalah $70 \mathrm{ml}$. Dengan dosis yang sama, yaitu $70 \mathrm{ml}$, pada penelitian ini, Temephos hanya membutuhkan waktu 7 jam, sedangkan ekstrak daun tembakau dan ekstrak daun jeruk purut membutuhkan waktu 12 jam.

\section{Pembahasan}

Temephos, ekstrak daun tembakau, dan ekstrak daun jeruk purut, dapat menjadi larvasida untuk membubuh nyamuk Aedes aegypti. Ketiganya hanya dibedakan oleh waktu dalam hal efektivitas. Ekstrak daun tembakau dapat menjadi larvasida. Hal ini sejalan dengan Zaidi, et al (2004) yang mengatakan bahwa tanaman tembakau mengandung alkaloid, flavonoid, minyak astiri, dan nikotin, sehingga tanaman tembakau dapat berpontesi sebagai larvasida. Ekstrak daun jeruk purut dapat menjadi larvasida. Hal ini sejalan dengan Dalimartha (2000) yang mengatakan bahwa daun jeruk purut memiliki kandungan minyak astiri, tannin, dan triterpenoid yang merupakan senyawa bioaktif larvasida. Temephos sudah lama digunakan di Indonesia sebagai larvasida. Abate (temephos) merupakan salah satu golongan dari pestisida yang digunakan untuk membunuh serangga pada stadium larva. Abate (temephos) yang digunakan biasanya berbentuk butiran pasir (sand granules) yang kemudian ditaburkan di tempat penampungan air dengan dosis $1 \mathrm{ppm}$ atau 1 gram untuk 10 liter air.

Pengendalian yang dilakukan adalah dengan membunuh larva dari vektor untuk memutus rantai penularannya dengan menggunakan abate (temephos). Abate berbentuk bubuk kristal padat dan segera larut saat dimasukkan ke dalam air. Di dalam air, abate akan bertahan beberapa hari kemudian mengalami degradasi. Dari segi kesehatan, abate dianggap tidak beracun terhadap manusia kecuali dalam dosis yang sangat besar.

Penggunaan abate (temephos) di Indonesia sudah sejak tahun 1976. Empat tahun kemudian yakni tahun 1980, abate (temephos) ditetapkan sebagai bagian dari program pemberantasan massal Aedes aegypti di Indonesia. Bisa dikatakan abate (temephos) sudah digunakan lebih dari 30 tahun (Felix, 2008).

\section{KESIMPULAN DAN SARAN Kesimpulan}

Berdasarkan hasil penelitian, maka kesimpulan yang dapat diambil adalah sebagai berikut: Temephos, ekstrak daun tembakau, dan ekstrak daun jeruk purut, dapat menjadi larvasida untuk membunuh larva Aedes aegypti. Temephos membutuhkan waktu 7 jam untuk membunuh semua larva dengan perbandingan dosis $70 \mathrm{ml} / 25$ ekor jentik Aedes aegypti.

Ekstrak daun tembakau membutuhkan waktu 12 jam untuk membunuh semua larva dengan perbandingan dosis $70 \mathrm{ml} / 25$ ekor jentik Aedes aegypti. Sedangkan, ekstrak daun jeruk purut membutuhkan waktu 12 jam untuk membunuh semua larva dengan perbandingan dosis $70 \mathrm{ml} /$ Aedes aegypti.

\section{Saran}

Bagi peneliti selanjutnya yang akan meneliti dengan tema yang sama disarankan untuk memperbesar dosis untuk mendapatkan hasil penelitian yang lebih bervariatif lagi. Bagi pemerintah, ekstrak daun tembakau dan ekstrak daun jeruk purut dapat menjadi larvasida alternatif untuk membunuh larva Aedes aegypti.

\section{DAFTAR PUSTAKA}

Anggraeni, D. (2011). Stop Tuberkulosis. Bee Media Indonesia, Jakarta. 
Bernhoft. (2010). A Brief Review on Biactive Compounds in Plants. Proceedings from a symposium. The Norwegian Acadey of Science and Letters, Oslo.

Budiman, A.K. (2009). Protein dan Asam Amino. Universitas Sumatera Utara, Medan.

Cahyono, B. (2005). Manfaat Jambu Mete. Tarat, Bandung.

Dalimartha, S. (2000). Atlas Tumbuhan Obat Indonesia. Trobus, Bogor.

Depkes. (2007). Cara Penularan Nyamuk Aedes Aegepty. Jakarta.

Dinas Kesehatan Jawa Tengah. (2003). Laporan Kesehatan Bulanan, Semarang.

Esy, Maryanti, dkk. (2017). Efektivitas Ekstrak Etano; Daun Jeruk Purut Sebagai Larvasida Nyamuk Aedes aegypti. Fakultas Kedokteran Universitas Riau, Riau.

Felix. (2008). Ketika Larva dan Nyamuk Dewasa Sudah Kebal terhadap Insektisida, Farmacia., 7 (7), 44.

Francisca. H.K. (1999). Ektraksi Atsiri dari Daun Jeruk Purut. Rineka Cipta, Jakarta.

Hadinegoro, SRH. (2002). Demam Berdarah Dengue. FK UI, Depok.

Jayaraman, S., MS. Manoharan, \& S Illanchezian. (2008). In-vitro Antimicrobial and antitumor activities of Stevia rebaudiana (Asteraceae) leaf extracts. Tropical Journal of Pharmaceutical Research. 7: 1143-1149.

Khalalia, R. (2016). Uji Daya Bunuh Granul Ekstrak Limbah Tembakau (Nicotianae Tabacum L.) Terhadap Larva Aedes Aegypt.

Kardinan, Agus. 2000. Pestisida Nabati: Ramuan dan Aplikasi. Rineka Cipta, Jakarta.

[USDA] United State Departement of Agriculture. (2015). Glycine soja. Redbean diakses pada tanggal 2 April 2016, jam 21.00 WIB dari http://www.plants.usda.gov/profile?symbol=PHVU.

Kemenkes. (2013). Nyamuk Aedes Aegepy. Kemenkes RI, Jakarta.

Komisi Pestisida. (1995). Media Standar Pengujian. Kementerian Pertanian, Jakarta.

Munawaroh dan Handayani. (2010). Ekstraksi Minyak Daun Jeruk Purut (Citrus hystrix D.C.) dengan Pelarut Etanol dan N-Heksana. Jurnal Kompetensi Teknik I (2): 73-78.

Setiawan dan Trisnawati. (1993). Cara Pembudidayaan, Pengelolaan, dan Pemasaran Tembakau. Penebar Swadaya, Jakarta.

Soegijanto, S. (2005). Demam Berdarah Dengue, Edisi 2. Airlangga, Jakarta.

Supartha, I.W. (2008). Pengendalian Terpadu Vektor Virus Demam Berdarah Dengue, Aedes aegypti (Linn.) dan Aedes albopictus (Skuse) (Diptera: Culicidae). Fakultas Pertanian Universitas Udayana, Denpasar.

Susanto. (2010). Katalis Heterogen. Universitas Indonesia, Depok.

Sudarmo, S. (2012). Pengendalian Hama dan Penyakit Tanaman Perkebunan. . Kanisius, Yogyakarta.

Suhendro, d. (2009). Demam Berdarah Dengue.dalam Buku Ilmu Penyakit Dalam. . Badan Penerbit FKUI, Jakarta.

WHO. (2009). Kharakteristik Nyamuk Demam Berdarah Donguen. WHO, USA.

Wibowo, F. (1997). Dasar-Dasar Produksi Program Televisi. Jakarta: Grasindo.

Zaidi, et al. (2004). The Big Five personality traits and their relationship with employee engagement among public sector university teachers of Lahore. African Journal of Bussiness Management. Vol. 7 (15). pp. 1344- 1353. DOI: 10.5897/AJBM12.290 